\title{
Rychlá metoda stanovení celkové objemové aktivity beta
}

\section{BARBORA SEDLÁŘOVÁ, EDUARD HANSLÍK, EVA JURANOVÁ}

Klíčová slova: rychlá metoda - stanovení celkové objemové aktivity beta - vzorky vod - kalibrace stronciem-90

\section{SOUHRN}

V souvislosti se zapojením vodohospodářských radiologických laboratoří do hodnocení mimořádné radiační události byl ve Výzkumném ústavu vodohospodáŕském TGM, v.v. i., (Vúv TGM) navržen a ověřen postup rychlého stanovení celkové objemové aktivity beta. Ve spolupráci s vodohospodářskými radiologickými laboratořemi Povodí, s.p., (dále VHRL) byl postup otestován v praxi. Poznatky z ověření se staly podkladem pro návrh normy, který byl projednán na oborovém středisku pro normalizaci Sweco Hydroprojekt, a.s., a následně v Subkomisi č. 4 Radiologické metody, která je součástí Technické normalizační komise č. 104. Po zahrnutí připomínek, včetně Úradu pro technickou normalizaci, metrologii a státní zkušebnictví, byla norma vydána v záŕi 2014 jako ČSN 757613 Kvalita vod - Rychlá metoda stanovení celkové objemové aktivity beta. Předmětem př́spěvku je shrnutí poznatků z ověřování postupu stanovení objemové aktivity beta rychlou metodou.

\section{ÚVOD}

V našich i zahraničních laboratořích se běžně provádí screeningové stanovení celkové objemové aktivity beta v povrchových, podzemních a pitných vodách. V závislosti na předúpravě vzorku, např. filtrací, je stanovována celková objemová aktivita beta $v$ rozpuštěných látkách (RL), nerozpuštěných látkách $(N L)$ nebo veškerých látkách (RL + NL). Většinou se používá tzv. odpařovací metoda, kdy je vzorek odpařen a odparek sušen nebo žíhán. Výsledný preparát se měři detekčním zařízením s proporcionálním detektorem [1]. Z toho vyplývá, že takto nelze stanovit radionuklidy těkavé při odpařování nebo žíhání, zejména izotopy jódu. Dále nejsou postiženy radionuklidy emitující nízkoenergetické záření beta. Tato metoda je běžně ve světě normována, např. mezinárodními normami ISO [2, 3], a dále národními normami např. v Německu [4], na Slovensku [5], ve Španělsku [6].

$\checkmark$ České republice se stanovení celkové objemové aktivity beta za běžné radiační situace provádí v laboratořích podle normy ČSN 757612 [7]. Vzorek se připraví odpařováním zpravidla jednoho až dvou litrů vzorku, aby bylo dosaženo splnění požadavku výše citované ČSN na plošnou hmotnost vyžíhaného odparku $10 \mathrm{mg} \cdot \mathrm{cm}^{-2}$. Vzorek se měří detekčním zařizením s proporcionálním detektorem. Jako standardní látka se použivá prírodní draslík se známým zastoupením draslíku-40. Príprava vzorku je časově náročná a pro účely hodnocení radiační mimořádné události nevhodná.

$\checkmark$ prípadě radiační mimořádné události je nutné zjistit míru kontaminace pitné vody co nejdřive po události. Pro účely havarijního screeningu není třeba dosahovat tak nízkých nejmenších detekovatelných aktivit a nejistot, jak je tomu $u$ běžných vzorkủ životního prostředí a $v$ pitné vodě. Pro radiační mimořádné situace stanovuje vyhláška SúJB [8] v souladu s nařizením rady EURATOM ve znění

Tabulka 1. Radionuklidy emitující beta částice uvažované po havárii jaderné elektrárny [11] Table 1. Radionuclides considered to be emitted during a nuclear power plant accident [11]

\begin{tabular}{|c|c|c|c|c|c|c|c|c|}
\hline Nuklid & $\begin{array}{l}\text { Atomové } \\
\text { číslo }\end{array}$ & $\begin{array}{l}\text { Hmotnostní } \\
\text { číslo }\end{array}$ & Poločas & Jednotka & $\begin{array}{l}\text { Dceřiný } \\
\text { radionuklid }\end{array}$ & Výtěžek & $\begin{array}{l}\text { Dceřiný } \\
\text { radionuklid }\end{array}$ & Výtěžek \\
\hline Ba-140 & 56 & 140 & 12,79 & $d$ & La-140 & 1,000 & & \\
\hline Ce-141 & 58 & 141 & 32,50 & $d$ & & & & \\
\hline Cs-137 & 55 & 137 & 30,17 & $r$ & $\mathrm{Ba}-137 \mathrm{~m}$ & 0,946 & & \\
\hline |-131 & 53 & 131 & 8,04 & $d$ & $X e-131 m$ & 0,011 & & \\
\hline La-140 & 57 & 140 & 40,22 & $\mathrm{~h}$ & & & & \\
\hline Ru-103 & 44 & 103 & 39,35 & $d$ & Rh-103m & 0,997 & & \\
\hline Sr-90 & 38 & 90 & 28,60 & r & Y-90 & 1,000 & & \\
\hline Te-131m & 52 & 131 & 30,00 & h & Te-131 & 0,222 & $\mid-131$ & 0,778 \\
\hline Y-90 & 39 & 90 & 64,1 & $\mathrm{~h}$ & & & & \\
\hline
\end{tabular}


pozdějších předpisů $[9,10]$ nejvyšší prípustné kontaminace potravin, které zahrnuji i pitnou vodu. Předpokládá se výskyt řádově vyšších aktivit, a proto je možné použít pro stanovení celkové objemové aktivity menší objem vzorku.

Z hlediska možné kontaminace povrchových vod v důsledku těžké havárie jaderné elektrárny se předpokládá výskyt beta záŕičů uvedených v tabulce 1 [11] Ke kalibraci stanovení celkové objemové aktivity beta se používají vedle draslíku-40 i stroncium-90 v rovnováze s ytriem-90 a cesium-137. Za běžné radiační situace má kalibrace draslíkem-40 tu přednost, že rozhodující podíl na celkové objemové aktivitě beta predstavuje právě beta aktivita draslíku-40. V případě havárie by naopak príspěvek draslíku-40 k celkové objemové aktivitě beta byl zcela zanedbatelný a znamenal by přibližně $0,1-0,2$ Bq. I $^{-1}$ a hlavní príspěvky by byly od radionuklidů uvedených v tabulce 1 .

Stroncium-90 při havárii naopak představuje jednu z významných složek radioaktivní kontaminace. $Z$ těchto důvodů bylo pro prípad hodnocení radiační mimořádné události ověřováno užití jako kalibračního preparátu stroncium-90 $\checkmark$ rovnováze s ytriem-90.

\section{Metodika}

Pro vybrané beta záriče (stroncium-90, cesium-137 a jód-131) byla stanovena účinnost měření $\eta, \vee s^{-1} \cdot \mathrm{Bq}^{-1}$, podle rovnice (1). Všechny používané etalony byly certifikovány a dodány Českým metrologickým institutem (ČMI).

$$
\eta=\frac{\frac{N_{e}}{t_{e}}-\frac{N_{p}}{t_{p}}}{A_{e}}
$$

kde $N_{e}$ je počet impulsů za dobu měření vzorku s etalonem;

$$
\begin{aligned}
& N_{p} \quad \text { počet impulsů za dobu měření pozadí; } \\
& t_{e} \quad \text { doba měření vzorku s etalonem, } v \text { s; } \\
& t_{p} \text { doba měření pozadí (prázdná miska), } v \mathrm{~s} \text {; } \\
& A_{e} \quad \text { aktivita etalonu }\left({ }^{00} \mathrm{Sr}_{-}{ }^{90} \mathrm{Y},{ }^{137} \mathrm{CS},{ }^{131} \mathrm{I}\right), \mathrm{v} \mathrm{Bq} \text {. }
\end{aligned}
$$

Vzorek pro stanovení účinnosti měření byl připraven přímým pipetováním malého objemu etalonu o známé aktivitě na měřici misku. Následně byl vzorek odpařen do sucha na sklokeramické desce CERAN 500 při teplotě $100{ }^{\circ} \mathrm{C}$. Odparek byl změřen detekčním zařízením EMS-3 alfa beta automat (fy Empos). Použité měřicí misky byly skleněné (fy EMPOS) o průměru $50 \mathrm{~mm}$ a výšce $7 \mathrm{~mm}$. V radiologických laboratořích jsou běžně dostupné a používají se na stanovení celkové objemové aktivity alfa postupem měření směsi odparku vzorku vody se scintilátorem ZnS (Ag).

Na základě stanovené účinnosti pro stroncium-90 v rovnováze s ytriem-90 byl podle rovnice (2) vypočten minimální objem vzorku $\vee$ v litrech pro př́pad hodnocení mimořádné radiační údálosti, kdy nejmenší detekovatelná objemová aktivita beta je menší než 100 Bq. I $^{-1}$.

$$
V=\frac{\frac{u^{2}}{\eta \cdot t_{v}}+2 \cdot u \frac{\sqrt{N_{p}\left(1+\frac{t_{p}}{t_{v}}\right)}}{\eta \cdot t_{p}}}{c_{\beta, N D}}
$$

kde $N_{p}$ je počet impulsů za dobu měření pozadí;
$t_{e} \quad$ doba měření vzorku s etalonem, $v$ s;
$t_{p} \quad$ doba měření pozadí (prázdná miska, $\vee \mathrm{s}$ );
$C_{\beta, N D}^{p}$ aktivita etalonu $\left.\left({ }^{90} \mathrm{Sr}^{-90}{ }^{90},{ }^{137} \mathrm{CS},{ }^{131}\right)\right), \vee \mathrm{Bq}$;
$\eta \quad$ účinnost, $\mathrm{v} \mathrm{s}^{-1} \cdot \mathrm{Bq}^{-1}$
u kvantil normálního rozdělení pro hladinu významnosti $95 \%, a=\beta=1,645$.

V rámci spolupráce s VHRL byla ověřována účinnost stanovení při použití kalibračního vzorku s etalonem stroncia-90. Dále byl testován vliv př́idavku inertní látky pro homogenní rozprostření odparku vzorku vody na měřicí misce. Velká pozornost byla věnována stabilizaci jódu-131 v odparku. Pro ověření stabilizace jódu-131 byl použit př́davek uhličitanu sodného a thiosíranu sodného v poměru 2: 1 při odpařování vzorku vody. Navržený prídavek směsi chemikálií byl převzat z ČSN ISO 9698 [12], kde je používán pro omezení těkání jódu při stanovení tritia destilací. Stabilizace jódu-131 v odparku byla vyhodnocena na základě porovnání účinnosti vypočtené podle ČSN 757612 [7], kdy namísto aktivity draslíku-40 byla do vzorce na výpočet účinnosti dosazena aktivita jódu-131 a z opakovaného měření připravených vzorků byla vypočtena experimentální preměnová konstanta.

Laboratoře VHRL použily při ověření detekční zařízení: EMS-3 alfa beta automat (fy EMPOS), NA 6201 alfa-beta POB 302 MC 2256 AK (fy EMPOS) a FHT (fy Canberra Packard). Použité měřicí misky byly skleněné (fy EMPOS) o průměru 50 mm a výšce $7 \mathrm{~mm}$. Pro měricí zařízení NA 6201 alfa-beta POB 302 MC 2256 AK byly použity skleněné misky o průměru $50 \mathrm{~mm}$ a výšce $5 \mathrm{~mm}$.

$\checkmark$ rámci ověřování postupu stanovení celkové objemové aktivity beta rychlou metodou poskytly VHRL údaje o době, která byla potřebná k prípravě vzorků, a o dosahovaných nejmenších detekovatelných objemových aktivitách beta. Na základě těchto údajů byla stanovena kapacita stanovení vzorků $\checkmark$ jedné laboratoři.

V posledním kroku ověřování metody uspořádala Zkušební laboratoř technologií a složek životního prostředí Vúv TGM, v. v.i., oddělení radioekologie ve spolupráci s VHRL zkoušky způsobilosti MP-RA-14. Vyhodnocení bylo provedeno podle ČSN ISO 5725-2 [13]. V roce 2015 byl zařazen vzorek na stanovení celkové objemové aktivity rychlou metodou beta ve zkouškách způsobilosti ZZ OR-RA-15 pořádaných ASLAB Střediskem pro posuzování způsobilosti laboratoři VÚV TGM, v. v.i.

\section{VÝSLEDKY A DISKUSE}

\section{Ověření účinnosti stanovení}

S ohledem na předpokládaný výskyt beta záričů v důsledku havárie jaderné elektrárny byly stanoveny účinnosti měření pro vybrané radionuklidy tabulky 1 . Pro stroncium-90 byla naměřena účinnost stanovení $0,28 \mathrm{~s}^{-1} \cdot \mathrm{Bq}^{-1}$, pro jód-131 byla účinnost $0,27 \mathrm{~s}^{-1} \cdot \mathrm{Bq}^{-1}$ a pro cesium-137 byla účinnost $0,15 \mathrm{~s}^{-1} \cdot \mathrm{Bq}^{-1}$. Pro rychlou metodu stanovení objemové aktivity beta bylo pro kalibraci zvoleno stroncium-90 z důvodu jeho poločasu přeměny 28,6 let a závažnosti z hlediska radiační kontaminace. $V$ rámci spolupráce $s$ VHRL bylo stanoveno z výsledků porovnávacích měření rozmezí hodnot účinnosti stanovení $(0,258-0,380) \mathrm{s}^{-1} \cdot \mathrm{Bq}^{-1}$ při použití preparátu stroncia-90. Z toho pro zařízení EMS-3 odpovídala účinnost průměrných hodnot rozmezí $(0,258-0,312) \mathrm{s}^{-1} \cdot \mathrm{Bq}^{-1}$, pro zařizení MC $2256 \mathrm{AK}$ $(0,260-0,380) \mathrm{s}^{-1} \cdot \mathrm{Bq}^{-1}$ a pro zařízení FHT 0,344 $\mathrm{s}^{-1} \cdot \mathrm{Bq}^{-1}$ [14]. Doba prípravy vzorků byla podle poskytnutých údajů 30-75 minut. Rozdíl v době prípravy vzorků v jednotlivých VHRL je způsoben technikou odpařování, zda byla použita topná deska s regulací teploty, nebo vodní lázeň, a dále v subjektivním vyhodnocení o dostatečném vysušení vzorku. Za předpokladu měření vzorku 2 × 500 s Ize konstatovat, že VHRL by byly schopné do 2 hodin od předání vzorku do laboratoře podat informaci o celkové objemové aktivitě beta z hodnocení měření minimálně tří vzorků. Celková kapacita jedné laboratoře by byla 24 vzorků za osmihodinovou pracovní dobu při kontrole pozadí po každém osmém vzorku. Pro zvolený režim měření všechny laboratoře VHRL dosahovaly požadovanou nejmenší detekovatelnou objemovou aktivitu beta méně než 100 Bq/l.

Pro lepší homogenní rozprostření odparku vzorku vody na měřicí misce bylo zvažováno použití inertní látky. Jako inertní látka byl testován silikagel 
o molární hmotnosti $\mathrm{M}=60,06 \mathrm{~g} \cdot \mathrm{mol}^{-1}$, síran vápenatý a chlorid sodný. Navážka inertní látky na měřicí misku byla o plošné hmotnosti 10 mg.cm², jak je dáno v normě ČSN 757612 [7]. Vyhodnocení bylo provedeno opět na základě stanovení účinnosti. Rozmezí hodnot účinnosti měření při použití preparátu stroncia-90 a navážky inertní látky silikagelu $v$ jednotlivých laboratořích bylo $(0,277-0,385) \mathrm{Bq}^{-1} \cdot \mathrm{s}^{-1}$.Z toho pro zařizení EMS-3 odpovídala účinnost průměrných hodnot rozmezí $(0,282-0,331) \mathrm{Bq}^{-1} \mathrm{~s}^{-1}$, pro zařízení MC $2256 \mathrm{AK}(0,277-0,385) \mathrm{Bq}^{-1} \cdot \mathrm{s}^{-1}$ a pro zařizení $\mathrm{FHT} 0,347 \mathrm{~Bq}^{-1} \cdot \mathrm{S}^{-1}$. Rozdíly účinností při použití síranu vápenatého a chloridu sodného ve srovnání s použitým silikagelem byly do $5 \%$. Ukázalo se, že použití inertní látky nepřináší významné zlepšení účinnosti stanovení celkové objemové aktivity beta rychlou metodou. Naopak manipulace s měřicí miskou při mísení vzorku a inertní látky pro zajištění stejnoměrné vrstvy je dosti komplikovaná. Z toho důvodu se pro rychlou metodu stanovení celkové objemové aktivity beta od použití inertní látky upustilo.

Výsledky stanovení účinnosti při použití preparátu stroncia a inertní látky (silikagelu) posloužily ke srovnání celkových objemových aktivit $v$ rámci radiační monitorovací sítě RMS [15]. Byly tak zjištěny pozad’ové hodnoty celkové objemové aktivity beta při kalibraci stronciem-90. Na deseti profilech povrchových vod určených pro úpravu na pitnou vodu sledovaných v rámci RMS v roce 2013 byly srovnány roční celkové objemové aktivity beta při kalibraci draslíkem a při kalibraci stronciem-90. Z grafu (obr. 1) vyplynulo, že nominální hodnoty takto stanovené celkové objemové aktivity beta jsou vyšší než při kalibraci draslíkem-40. Poměr účinností stanovení při kalibraci draslíkem-40 a při kalibraci stronciem- 90, $\eta_{k 40} / \eta_{\text {srod }}$ byl v rozmezí 1,1-1,4 pro vzorky RMS stanovené v laboratořích VHRL.

Porovnání celkové objemové aktivity beta při kalibraci draslíkem-40 a při kalibraci stronciem-90 ukazuje, že budou měřeny hodnoty větší. Při jaderné nehodě by však zanikl příspěvek draslíku-40, protože jeho pozadí při běžných koncentracích draslíku v povrchových vodách $5 \mathrm{mg} . \mathrm{I}^{-1}$ by zpracování $5 \mathrm{ml}$ vzorku při rychlém stanovení celkové objemové aktivity beta znamenalo množství draslíku na měricí misce 0,025 mg, a tedy zanedbatelnou aktivitu méně než 1 mBq.

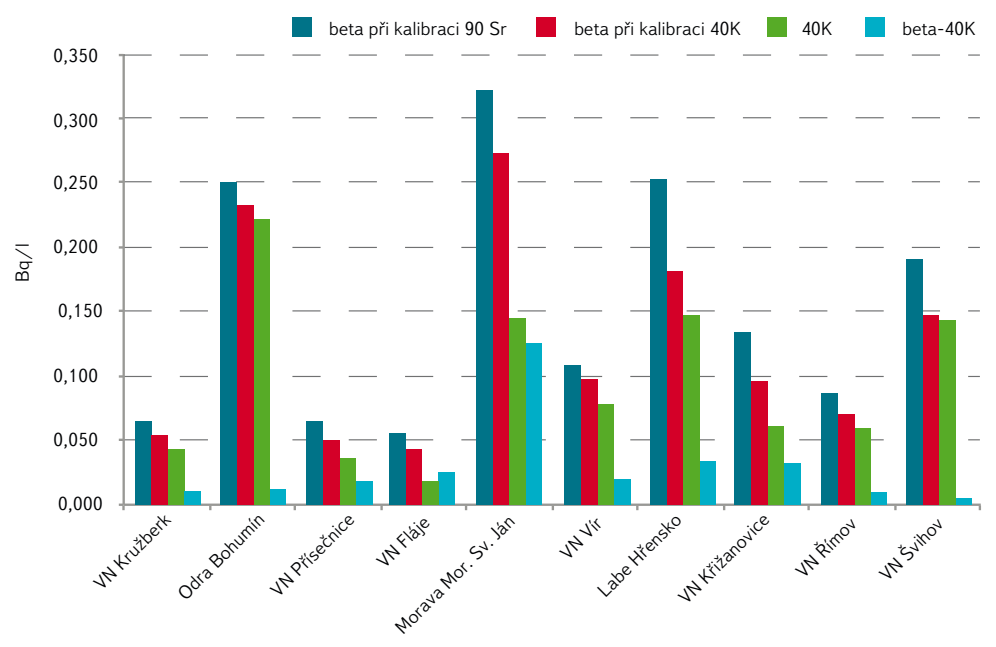

Obr. 1. Celková objemová aktivita beta veškerých látek při kalibraci Sr-90, celková objemová aktivita beta veškerých látek při kalibraci K-40, objemová aktivita K-40 a celková objemová aktivita beta veškerých látek při kalibraci K-40 po odečtení draslík-40 pro zájmová odběrová místa RMS v roce 2013

Fig. 1. The gross beta activity of total solids, calibrated using Sr-90, the gross beta activity of total solids, calibrated using K-40, beta activity of K-40 and the gross beta activity of total solids, calibrated using K-40 after subtraction of the potassium-40 activity at the sampling points of RMS in 2013

\section{Ověření stabilizace jódu-131}

Pro ověření stabilizace jódu-131 byl použit přídavek směsi uhličitanu sodného a thiosíranu sodného v poměru $2: 1$. Na základě testu sady vzorků o navážce směsi uhličitanu sodného a thiosíranu sodného (3,75-200) mg se ukázalo, že již malé množství prídavku směsi zajistí, že nedojde během prípravy vzorku odparením při $100{ }^{\circ} \mathrm{C}$ k uvolnění jódu z odparku (obr. 2) [16]. Ve spolupráci s laboratořemi VHRL a VúV bylo provedeno porovnání stabilizace jódu-131. Hodnoty účinností pro jód-131 byly $v$ intervalu $(0,260-0,375) \mathrm{Bq}^{-1} \cdot \mathrm{s}^{-1}$. Laboratoře VHRL a VúV dosahovaly dobré shody hodnot účinností pro jód-131 při opakovaných měřeních v intervalech po cca 4, 7, 10 a 14 dnech od prvního měření. Experimentálně vypočtené přeměnové konstanty jód-131 byly $v$ rozmezí $(0,081-0,088) d n e^{-1}, t j$. odpovídající poločasy přeměny byly v rozmezí $(7,88-8,61)$ dne. Teoretická přeměnová konstanta pro jód-131 je 0,086 den ${ }^{-1}$, tj. odpovídající poločas přeměny je 8,04 dne. Na základě dobré shody experimentální a teoretické přeměnové konstaty jódu-131 byla prokázána dobrá stabilizace jód-131 thiosíranem sodným a uhličitanem sodným při prípravě vzorku odpařením při teplotě $100{ }^{\circ} \mathrm{C}$. Součástí postupu pro stanovení celkové objemové aktivity beta rychlou metodou je proto prídavek $0,05 \mathrm{ml}$ směsi uhličitanu sodného a thiosíranu sodného o koncentraci $150 \mathrm{~g} . \mathrm{l}^{-1}$ uhličitanu sodného a $75 \mathrm{~g} . \mathrm{I}^{-1}$ thiosíranu sodného.

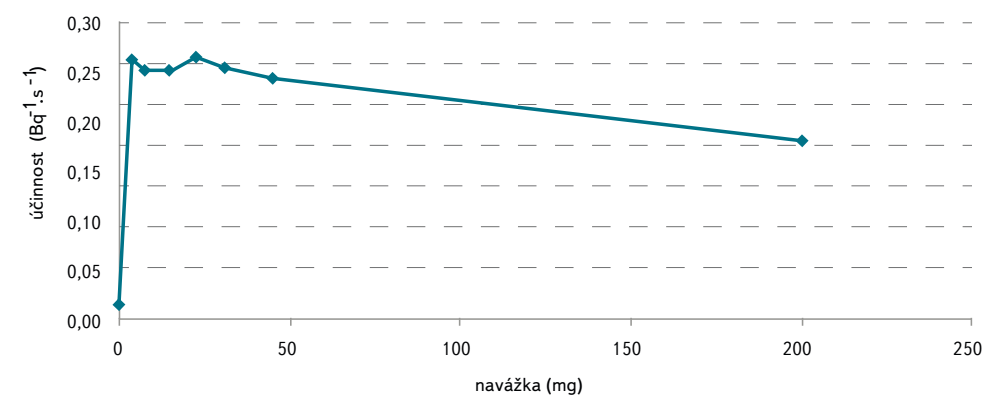

Obr. 2. Účinnost stanovení celkové objemové aktivity beta vztažené na jód-131 pro různé navážky uhličitanu sodného a thiosíranu sodného v poměru $2: 1$ na měřicí misce Fig. 2. Efficiency of the determination of the gross beta activity related to iodine 131 for different fills of sodium carbonate and sodium thiosulfate in the ratio of $2: 1$ in the planchette

\section{Zkoušky způsobilosti pro ukazatel celková objemová aktivita beta rychlou metodou}

Pro ověření navrženého postupu stanovení celkové objemové aktivity beta rychlou metodou pro hodnocení mimořádné radiační události uspořádala radiologická laboratoř při VúV TGM, v.v.i., ve spolupráci s VHRL v roce 2014 zkoušku způsobilosti MPZ-RA-14 [17]. Celkem se zúčastnilo sedm laboratoří. V následujícím roce 2015 byl zařazen vzorek pro stanovení celkové objemové aktivity beta rychlou metodou v ZZ OR-RA-15 pořádaných ASLAB Střediskem pro posuzování způsobilosti laboratoří VúV TGM, v.v.i. Celkem se zúčastnilo 21 laboratoří s různým zaměřením (obr. 3). Hodnocení stanovení ukazatele celková objemová aktivita beta rychlou metodou bylo provedeno podle CSN ISO 5725-2 [13]. Výsledky jsou uvedeny $v$ tabulce 2. V rámci ZZ OR-RA-15 poskytly laboratoře informace o době př́pravy vzorku. Na základě těchto údajủ bylo potvrzeno, že kapacita jedné laboratoře za osmihodinovou pracovní dobu je asi 24 vzorků. 


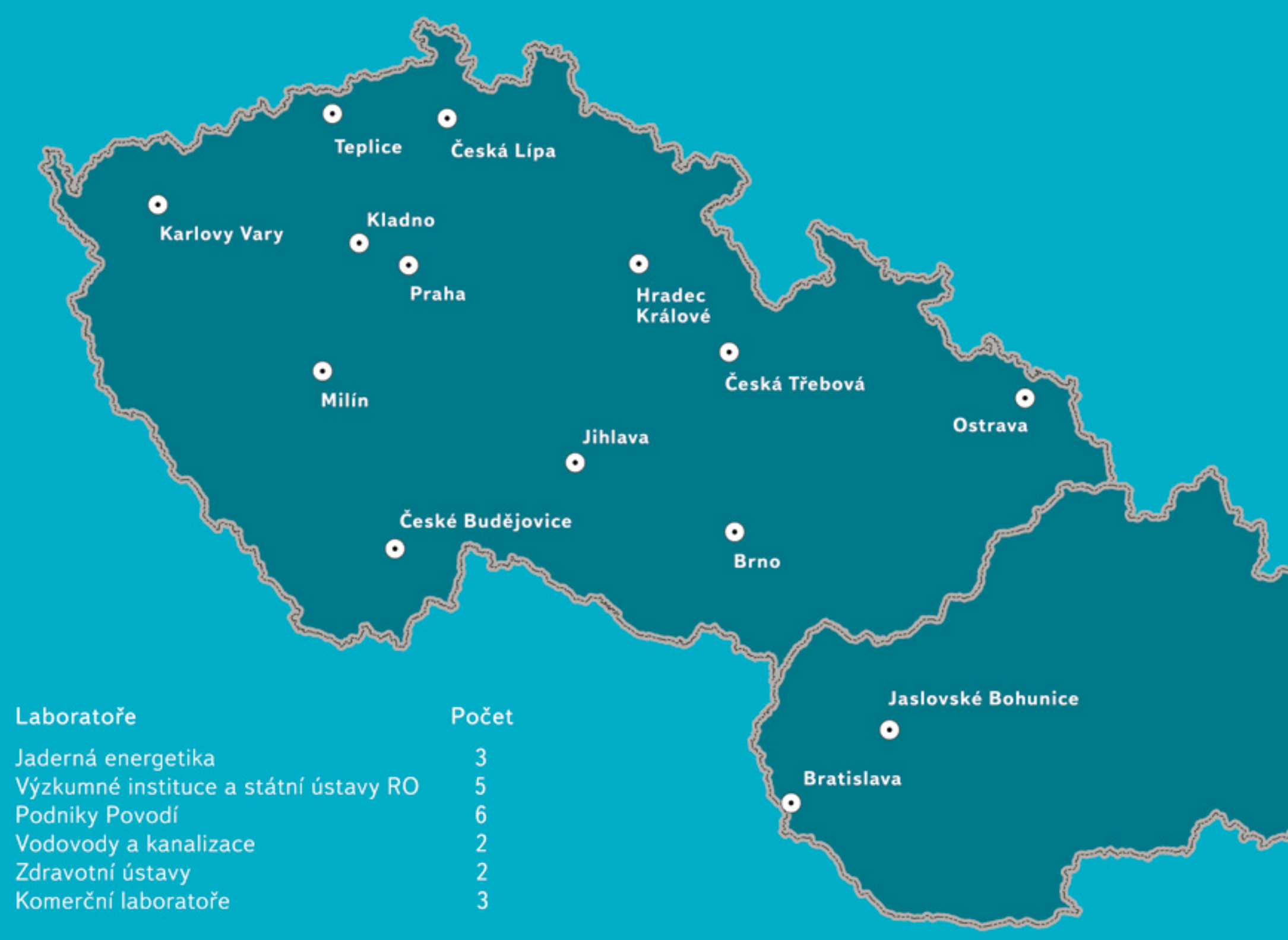

Obr. 3. Rozložení zúčastněných laboratoři v ZZ OR-RA-15 v České republice a Slovenské republice

Fig. 3. Distribution of the participating laboratories in ZZ OR-RA-15 in the Czech Republic and the Slovak Republic

Tabulka 2. Výsledky statistického zpracování ZZ MPZ-RA-14 a ZZ OR-RA-15 Table 2. Results of statistical assessment of ZZMPZ-RA-14 and RA-ZZ OR-15

\begin{tabular}{|c|c|c|c|c|c|c|c|c|c|c|}
\hline Označení & Druh vzorku & $\mathbf{L}$ & $\mathbf{n}$ & $n_{0}$ & $\begin{array}{l}\mathrm{x} \\
\mathrm{Bq} / \mathrm{I}\end{array}$ & $\begin{array}{l}x_{\text {ref }} \\
\mathrm{Bq} / \mathrm{I}\end{array}$ & $\begin{array}{l}\mathrm{s}_{\mathrm{r}} \\
\mathrm{Bq} / \mathrm{I}\end{array}$ & $V C_{r} \%$ & $\begin{array}{l}S_{R} \\
B q / I\end{array}$ & $V C_{R} \%$ \\
\hline MPZ-RA-14 & uměle připravený vzorek & 7 & 14 & 0 & 188 & 184 & 18 & 9,6 & 20 & 10,6 \\
\hline OR-RA-15 & uměle připravený vzorek & 21 & 42 & 0 & 462 & 456 & 19 & 4,2 & 29 & 6,2 \\
\hline
\end{tabular}

\begin{tabular}{llll}
\hline$L$ & počet zúčastněných laboratoři & $S_{r}$ & směrodatná odchylka opakovatelnosti \\
\hline$n$ & počet hodnot pro danou objemovou aktivitu & $V C_{r}$ & variační koeficient opakovatelnosti \\
\hline$n_{0}$ & počet odlehlých hodnot & $S_{R}$ & směrodatná odchylka reprodukovatelnosti \\
\hline$x_{\text {ref }}$ & celkový průměr & $V C_{R}$ & variační koeficient reprodukovatelnosti \\
\hline
\end{tabular}




\section{Navržený postup stanovení celkové objemové aktivity beta rychlou metodou}

Navržený postup stanovení a provedená ověření se staly podkladem pro normu ČSN 757613 Kvalita vod - Rychlé stanovení celkové objemové aktivity beta [18]. Metoda je založena na prímém měření odparku malého množství vzorku nízkopozad'ovým detekčním zařízením. Malý objem vzorku s prídavkem směsi tiosíranu sodného a uhličitanu sodného je pipetován prímo na měřicí misku. Následně je vzorek odpařen do sucha prí teplotě $100{ }^{\circ} \mathrm{C}$ a měřen. Pro kalibraci je použit etalonový roztok stroncia-90 v radioaktivní rovnováze s ytriem-90. Pro stanovení pozadí je měřena prázdná měřicí miska. S ohledem na splnění požadavku pro nejmenší detekovatelnou objemovou aktivitu beta méně než 100 Bq..$^{-1}$ byl zvolen objem zpracovávaného vzorku $3 \mathrm{ml}$. Doba měěení vzorku, kalibračního vzorku a pozadí byla dána 2 × 500 s. Celková objemová aktivita beta je vypočtena podle rovnice (3):

$$
c_{\beta}=\frac{\frac{N_{v}}{t_{v}}-\frac{N_{p}}{t_{p}}}{\eta \cdot V}
$$

kde $N_{v}$ je počet impulsů za dobu měření vzorku;

$t_{v} \quad$ doba měření vzorku, $v \mathrm{~s}$;

$N_{p} \quad$ počet impulsů za dobu měření pozadí;

$t_{p} \quad$ doba měrení pozadí, $v$ s;

$\checkmark$ objem vzorku zpracovaného na preparát po odečtení objemu činidel prídaných pro konzervaci, $\vee$ l;

$\eta \quad$ účinnost měření, $v \mathrm{~Bq}^{-1} . \mathrm{s}^{-1}$, podle rovnice (4):

$$
\eta=\frac{\frac{N_{k}}{t_{k}}-\frac{N_{p}}{t_{p}}}{2 \cdot A_{k}}
$$

kde $N_{k}$ je počet impulsů za dobu měření vzorku pro kalibraci;

$t_{k} \quad$ doba měření vzorku pro kalibraci, $v$ s;

$A_{k} \quad$ aktivita ${ }^{90} \mathrm{Sr}$ ve vzorku pro kalibraci, $v \mathrm{~Bq}$.

\section{ZÁVĚR}

S ohledem na vybavení VHRL byl postup pro hodnocení mimořádné radiační události navržen tak, aby měření vzorku bylo prováděno na měřicím zařizení s proporcionálním detektorem. Navržený postup při zpracování $3 \mathrm{ml}$ vzorku $v$ režimu měření vzorku, kalibračního vzorku a pozadí 2 × 500 s splňuje podmínku, že nejmenší detekovatelná celková objemová aktivita beta je menší než 100 Bq..$^{-1}$. V závislosti na prípravě vzorků pred měřením a době měření by první tři výsledky od předání vzorku do laboratoře byly známy do 2 hodin. Kapacita jedné laboratoře by byla 24 vzorků během osmihodinové pracovní doby s kontrolou měření pozadí po každém cca osmém vzorku.

Norma ČSN 757613 byla vypracována pro získání jednotného postupu při hodnocení mimořádné radiační situace. Nepředpokládá se rutinní zavedení tohoto postupu do systému kvality jednotlivých radiologických laboratoří. Z důvodu připravenosti laboratoří použít jednotný postup podle ČSN 757613 a zapojit se do hodnocení prípadné mimořádné radiační události je plánováno zařazení vzorku na stanovení ukazatele celé objemové aktivity beta rychlou metodou do zkoušek způsobilosti ZZ OR-RA pořádaných ASLAB VúV TGM, v.v. i., s četností 1x za dva až tři roky.

\section{Poděkování}

Přispěvek byl zpracován s podporou bezpečnostního výzkumu MV-24236-42/P-2010.

\section{Literatura}

[1] RICE, E.W., BAIRD, R.B., EATON, A.D., and CLASCERI, L.S. Standard methods for the examination of water and wastewater. 22st Edition, 2012, p. 7-15 - 7-18, ISBN 978-0875530130.

[2] ISO 10704 Jakost vod - Měření celkové aktivity alfa a beta v neslaných vodách - Metoda depozice tenké vrstvy, 2009.

[3] ISO 9697 Jakost vod - Měreni objemové aktivity beta v neslaných vodách - Metoda tlusté vrstvy, 2008.

[4] DIN 38404-15 German standard methods for the examination of water, waste water and sludge: physical and physic-chemical parameters (group C); determination of beta activity per unit volume in drinking water, ground water, surface water and waste water (C 15), 1987.

[5] STN 757612. Kvalita vody. Rádiologické ukazovatele. Celková objemová aktivita beta, 2005.

[6] UNE 73311-4. Determination of the total beta activity index in water by means of a proportional meter, 2002.

[7] ČSN 757612 Jakost vod - Stanovení celkové objemové aktivity beta, ČNI, Praha, 2004

[8] Vyhláška SúJB č. 307/2002 Sb., o radiačni ochraně ve znění vyhlášky SúJB č. 499/2005 Sb.

[9] Nařízení Rady EURATOM č. 3954/87 ze dne 22. prosince 1987, ve znění Nařízení Rady EURATOM č 2218/89 ze dne 18. července 1989, kterým se stanoví nejvyšší př́pustné úrovně radioaktivní kontaminace potravin a krmiv po jaderné havárii nebo jiném prípadu radiační mimořádné situace. Úrední věstník Evropskéunie, 1987.

[10] Doporučení Komise 2000/473/Euratom ze dne 8. června 2000 o aplikaci článku 36 Smlouvy o Euratomu týkajíci se monitorování úrovní radioaktivity v životním prostředí pro účely posuzováni expozice populace jako celku.

[11] MIŠÁK, J. a POKORNÁ, O. Doplňujicí informace k analýzám těžkých havárií pro dokumentaci EIA NJZ ETE. EGP-5010-F-101049, 2010 .

[12] ČSN ISO 9698 (75 7635) Jakost vod - Stanovení objemové aktivity tritia - Kapalinová scintilační měricí metoda. ÚNMZ, Praha, 2011

[13] ČSN ISO 5725-2 Přesnost (správnost a shodnost) metod a výsledků měření - Část 5: Alternativní metody pro stanovení shodnosti normalizované metody měření, ČNI, Praha, 1999.

[14] HANSLÍK, E., SEDLÁŘOVÁ, B., LIŠKA, M., LANGHANS, J., BEDNÁREK, J., MEDEK, J., BURIAN, M. a JUSKO, J. Ověření účinnosti pro rychlou metodou stanovení celkové objemové aktivity beta spolupráce vodohospodářských laboratoří Povodí, státní podnik a VÚV TGM, v.v.i. XXI. Konzultačné dni pro pracovníkov vodohospodarskych rádiologickych laboratórii, Banská Štavnica, 2013, s. 68-73, ISBN 978-80-89062-96-6.

[15] HANSLÍK, E., SEDLÁŘOVÁ, B. a MAREŠOVÁ, D. Porovnání hodnot celkové objemové aktivity beta při kalibraci draslíkem 40 a stronciem 90 - ytriem 90. XXI. Konzultačné dni pro pracovníkov vodohospodarskych rádiologickych laboratórii, Banská Śtavnica, 2013, s. 13-15, ISBN 978-80-89062-96-6.

[16] HANSLÍK, E., SEDLÁŘOVÁ, B., LIŠKA, M., LANGHANS, J., BEDNÁREK, J., MEDEK, J., BURIAN, M. a JUSKO, J. Rychlé stanovení celkové objemové aktivity beta ve vodách - I. část. Radiologické metody $\checkmark$ hydrosfére 13, Buchlovice, 2013, s. 20-27, ISBN 978-80-86832-71-5.

[17] SEDLÁŘOVÁ, B. a HANSLIÍK, E. Rychlá metoda stanovení celkové objemové aktivita beta podle ČSN 75 7613. Radiologické metody v hydrosfére 15, Uherské Hradiště, 2015, s. 10-15, ISBN 978-80-86832-84-5.

[18] ČSN 757613 Kvalita vod - Rychlá metoda stanovení celkové objemové aktivity beta, ÚNMZ, 2014.

\section{Autoři}

Ing. Barbora Sedlářová

凶barbora_sedlarova@vuv.cz

Ing. Eduard Hanslík, CSc.

凶eduard_hanslik@vuv.cz

Ing. Eva Juranová

凶eva_juranova@vuv.cz

Výzkumný ústav vodohospodářský T. G. Masaryka, v. v. i., Praha

Príspěvek prošel lektorským řizením. 
